\title{
A combined research agenda towards integrated conservation and development for Madagascar
}

\author{
Jörg U. Ganzhorn
}

\begin{abstract}
Better integration of social and natural science activities seems to be the key to improve the efficiency of conservation and development. While there is no recipe for success, this paper argues that conservation has to pay for itself if it wants to be anchored in present-day-societies. In systems where humans depend largely on subsistence activities, economic benefits from conservation must outweigh the benefits from increasing these activities. Coming from a natural science perspective, this paper proposes some activities that could improve the basis for decision-making and contribute to the long-term integration of sustainable conservation and development. It is argued that experiences from various projects must be evaluated and be accessible; data should be stored in a central database that can be used to develop future programs; restoration of various sorts providing direct income for the local human populations (including gardens, native and exotic tree plantations with valuable species) should be a priority; and natural science projects should add analyses of processes to the present preponderance of describing patterns. All these activities should result in integrated action to maintain natural biodiversity as a key component to maintain and improve local livelihoods.
\end{abstract}

\section{RÉSUMÉ}

La clef de la réussite pour assurer la protection de la nature et le développement passe par une meilleure intégration des activités élaborées dans le cadre des sciences sociales et celui des sciences naturelles. L'objet n'est pas ici d'énoncer les ingrédients d'une utopique recette miracle mais de montrer que la protection de la nature doit être assimilée à une activité rentable si elle veut s'ancrer dans la réalité quotidienne des sociétés humaines. Dans des systèmes où les gens sont étroitement liés aux activités de subsistance, les avantages économiques de la conservation de la nature doivent dépasser ceux de I'augmentation des activités de subsistance. En partant d'une perspective des sciences naturelles, cet article propose de considérer quelques points qui pourraient améliorer les fondements dans toute prise de décision et qui pourraient contribuer à établir une base qui servira à l'intégration à long terme de la conservation et du développement durables. Ce plaidoyer porte sur les points suivants: (1) Les expériences acquises dans les différents projets doivent être évaluées et archivées afin d'être accessibles aux élaborateurs de nouveaux projets

\author{
University of Hamburg \\ Biocenter Grindel and Zoological Museum \\ Department of Animal Ecology and Conservation \\ Martin-Luther King Platz 3, 20146 Hamburg, Germany \\ E-mail: ganzhorn@zoologie.uni-hamburg.de
}

à venir. (2) Les données doivent être stockées dans une base de données centrale qui pourra être utilisée pour élaborer de futurs programmes destinés à la gestion pérenne des espaces. Elle devra contenir les résultats de recherches intégrées et croisées sur plusieurs disciplines, de recherches appliquées aux problèmes pour les hommes et en même temps des résultats de recherches de base sur les sciences naturelles. Cet ensemble devra être accessible pour fournir des services et des conseils aux politiques, aux décideurs et aux intervenants. (3) Les activités de restauration de toutes sortes devraient être prioritaires. Il en est de la réhabilitation des jachères ou de la restauration d'écosystèmes naturels, et on trouvera des activités menées dans des jardins, des cultures de rente, des plantations arborées d'essences recherchées, qu'elles soient indigènes ou allogènes, et des habitats originels. La mosaïque d'habitats doit être élaborée de telle manière qu'elle permettra de produire des revenus directs pour les gens de la région, d'une façon ou d'une autre. Les recherches portant sur la nature devraient limiter la prépondérance actuelle à décrire des schémas pour aborder davantage des analyses portant sur les processus et fonctions. Ces analyses devraient tenter de comprendre les processus sous-jacents qui expliqueraient, non seulement la répartition actuelles des espèces mais aussi les services et fonctions fournis par les écosystèmes. Toutes ces activités devraient aboutir à des actions intégrées pour maintenir la biodiversité naturelle en tant que composante clef pour maintenir et améliorer les moyens d'existence locaux.

KEYWORDS: Restoration, database management, ecosystem function, ecosystem process.

MOTS CLEFS : Restauration, base de données, fonctions et services écosystémiques, processus écologiques.

\section{CONTEXT}

It is not very useful to grieve over the demise of Madagascar's original forest ecosystems in yet another publication. Rather, we should make an honest evaluation of what went wrong, why hundreds of millions of dollars and euros targeted for conservation and aid were unable to turn the tide (e.g., Rabesahala Horning 2008), what are the old and new challenges, and what can we do to save whatever is left. As an ecologist I have little so say about misjudgments of the social, economic and political context that contributed to the problems of effec- 
tive nature conservation. Rather, from the perspective of a natural scientist, I provide some thoughts on what could be done to help improve the prerequisites for more effective conservation of Madagascar's biota and human livelihoods.

\section{PROJECT REVIEW}

With his superb background and insights, Jeffrey Sayer provided a thoughtful analysis of the current conservation and development situation in Madagascar and elsewhere (Sayer 2009). One central point of his conclusion was a call to "learn from mistakes" rather than "hiding mistakes" (see Table 1 in Sayer 2009). In order to achieve this goal, project results must be documented and documents must be available for further analyses, evaluation and as bases for the next generation of projects. However, data and documents are not available for most projects once they have come to an end. As a result, projects and mistakes are replicated over and over again without any chance to learn from past mistakes. Apart from the lack of documentation, most of the staff has been changed by the time a new project starts, and only few people remain long enough in this field to accumulate enough knowledge for comprehensive analyses (e.g., Durbin et al. 2003, 2008, Rabesahala Horning 2003, Sorg 2006, Elmqvist et al. 2007, Ratsirarson 2008). Thus, there is a need for a centralized structure for data storage, management and analyses.

\section{DATA MANAGEMENT}

About 20 years ago, a group of NGOs and Malagasy governmental institutions planned a 'Biodiversity Planning Center' for Madagascar (Smith et al. 1997). The center was to compile and store data from all kinds of conservation oriented projects. Projects carried out in Madagascar would have been obliged to deposit their data in the Center (certainly with appropriate copyright regulations; but after all, most of the work is funded by the public and therefore the public has the right to have access to the data if the people who compiled the data do not find the time to analyze and publish them). A central database and skilled data management would allow new project developers to learn what has been done already, to apply comparable methods and to address gaps in knowledge rather than duplicate efforts. This database should also have allowed meta-analyses of the reasons for successes and failures. Unfortunately, the project was not implemented. For some of the biodiversity data, this task has been taken on by private initiatives. It is no surprise that analyses of these data serve as important drivers for conservation decisions today and serve to prioritize geographical regions for conservation efforts (Wilmé et al. 2006, Kremen et al. 2008, Missouri Botanical Garden 2010, REBIOMA 2010).

Twenty years after the failure to establish such a center in Madagascar, the idea of centralized data management centers has begun to root in the political arena internationally. Thus, today, there might be more political and financial support to implement such a center than has been a few decades ago. As an example, the German government recently launched a major project to help set up Regional Science Service Centres for Adaptation to Climate Change and Sustainable Land Management (RSSC 2010) in western and southern Africa. On their webpage it states:

"This center (or a series of regional centers) should create added value by complementing the existing research and capacity development infrastructures and research initiatives. It should be embedded in the regional and national research. Its mission is to conduct problem-oriented research in the area of adaptation to climate change and sustainable land management. It should provide evidence-based advice for all decisionmakers and stakeholders to improve the livelihoods of people in the region and to contribute to the creation of an African knowledge-based society. In order to meet the demands of target groups such as policy-makers and governmental administration, farmers, practitioners and other regional and local stakeholders affected by climate change, the center(s) should have the following three main objectives that are closely interrelated and that should be take into account with equal priority:

1. Trans-disciplinary, applied research for people

2. Services and advice for policy, decision-makers and stakeholders

3. Capacity development (RSSC 2010)."

This statement could easily describe the present situation in Madagascar. In principle, all aspects mentioned in the concept for the RSSC are available in Madagascar. The pieces of the puzzle simply ought to be combined. Madagascar could then be the front-runner and model of the new concept of "earth system science for global sustainability", the new political mainstream and call for better integration of social science research into the concepts for sustainable development (Reid et al. 2010). Thus, the concept of a 'Biodiversity Planning Center' for Madagascar should be revived, explicitly extended to include social sciences and adapted to suit the needs for development projects. With the appropriate structures put in place, there might be a chance for external funding, though this project would require a national financial perspective; and probably could be financed with the money coming into the country right now if activities were coordinated by a central structure.

\section{RESTORATION}

Assuming that conservation and development objectives can be achieved within the regional Malagasy socio-economic and cultural context, what may be the directions for future activities? On the human side, the very basic assumption is that people need to make money, they want to make money and they will make more money if the opportunity arises. On the natural history side, the present conclusion is that the current system of protected areas is insufficient to maintain the island's biodiversity under the scenario of climate change (Hannah et al. 2008). Especially in the west but also in the east, protected areas are isolated without connectivity to other protected areas. If the long-term trend of desiccation will continue, organisms will have to be able to retreat from dry areas to more mesic refugia. Since climate change is happening in Madagascar, can be documented with contemporary data within a decade (such as between the mid 1980s and the mid 1990s: Raxworthy et al. 2008), and is expected to result in pronounced changes until 2050 (Direction Générale de la Météorologie 2009), there is an urgent need for a comprehensive analysis for future land management.

From the perspective of biodiversity conservation, the only solution to properly address the problem of lack of connectivity seems to be to restore natural habitats between protected areas 
assuming that the protected areas will be protected for some time to come (Holloway 2003). This integration of anthropogenic and 'pristine' ecosystems is one of the developing research avenues for the near future (Ellis and Ramankutty 2008). Restoration can take a variety of forms. The oldest record of forest restoration in Madagascar comes from the mountains of Ankaratra where some sort of clear-cut area has been reforested with a monoculture of native trees about 200 years ago (Goodman et al. 1996). The assemblages of bird and mammalian insectivores and rodents do not seem to differ markedly from pristine forests of the same altitude. Apart from these reports mentioned above, the documented experiences with natural forest restoration in Madagascar are very limited, as is the information of the endemic biodiversity response to anthropogenic habitats (Irwin et al. 2010).

Most reforestation projects have been done with exotic trees to cover the needs of the human population for charcoal, firewood, wood for construction, and to reduce the pressure on the remaining forest. During the last few years, many local restoration and reforestation activities with native trees have been implemented. But given that for decades GOs and NGOs have been aware that the native forest disappears and has to be replaced to maintain its services not just to maintain biodiversity but also to maintain the livelihoods for the people, it is astonishing that the largest non commercial nursery for native trees in Madagascar is run by a mining company, QIT Madagascar Minerals, with more than 30,000 trees from 200 native species produced until now (Randriatafika et al. 2007a, Vincelette et al. 2007, Rabenantoandro, pers. comm. 23 August 2010).

Restoration can be more than 'just' planting native trees. Restoration in an anthropogenic landscape could consist of a mosaic of habitats that can provide connectivity, such as gardens (not yet integrated in Madagascar, but elsewhere: Goddard et al. 2010), exotic trees (Ganzhorn 1987, Vallan 2002), wetlands (Durbin et al. 2003, 2008, Randriatafika et al. 2007b), agroforestry and native plants that are of immediate use or economic value for the local people (Schroth et al. 2004). Apart from plants that occur in monocultures naturally, such as reeds, utilitarian plants such as trees (Deleporte et al. 1996) or lianas (Rabenantoandro et al. 2007) might be planted as enrichment plantations. The recent pillage of rosewood illustrates the need but also the potential for enrichment plantations to compensate for the loss of rosewood trees and to provide valuable resources for future generations (Patel 2009, Wilmé et al. 2009, Innes 2010, Randriamalala and Liu 2010). In addition, precious trees could also be planted around gardens to serve as a 'bank account' for individual farmers as it is being done in the Amazon (Serra01995), or, together with fruit trees, again as enrichment plantations in secondary vegetation. In addition to these approaches there are political incentives, such as added value through carbon credits (Hunt 2008), Reducing Emissions from Deforestation and Forest Degradation (REDD) (Plugge et al. 2010), or yet unexplored economic compensation for biodiversity values (Bishop et al. 2008).

In the short-term, immediate benefits from conservation and sustainable land management must exceed benefits from unsustainable land management. As a long-term perspective, people will have to acquire the insight that resources are limited. In the case of Madagascar, that the forest ends at the top of the mountain and that there will just not be any place to go once the top of the mountain has been cleared for agriculture.
These types of insight and foresight are not found commonly in activities of western or in the new sky-rocketing economic cultures, such as Brazil or China, either, but the implementation of the existing laws is easier in western culture as there are options to generate alternative income that are not available to most farmers in Madagascar. Irrespective of the short-term solution and possible long-term change in perception of land management, it would be naïve to expect that somebody will always be there to compensate for missed income. At the end of the day conservation must pay its way by itself.

\section{FUTURE DIRECTIONS FOR RESEARCH}

Recent buzzwords for research agendas and international funding include calls for a better understanding of ecosystem functions (ESF) and ecosystem services (ESS). Ecosystem functions are defined as "the capacity of natural processes and components to provide the goods and services that satisfy human needs, directly or indirectly" (de Groot et al. 2002: 394). Thus, they represent interactions between biotic and abiotic components of ecosystems. Based on 'The Millenium Ecosystem Assessment' (2005) and subsequent summaries (e.g., Carpenter et al. 2009) three categories of ecosystem services can be identified: provisioning services, regulating services and cultural services. These ESS and ESF are exemplified for the Mahafaly Plateau in Table 1.

TABLE 1. Ecosystem services and ecosystem functions possibly relevant on the Mahafaly Plateau (modified from SuLaMa, unpubl. grant application to BMBF, Germany).

\begin{tabular}{|c|c|c|}
\hline Service & Example & Ecosystem function \\
\hline \multicolumn{3}{|c|}{ Provisioning Services } \\
\hline $\begin{array}{l}\text { Water } \\
\text { supply }\end{array}$ & $\begin{array}{l}\text { Drinking water for } \\
\text { humans, livestock and } \\
\text { wildlife, rainfed agriculture } \\
\text { and irrigation }\end{array}$ & $\begin{array}{l}\text { Run-off, infiltration, } \\
\text { subterranean supply }\end{array}$ \\
\hline $\begin{array}{l}\text { Agricultural } \\
\text { Crops and } \\
\text { Fruit }\end{array}$ & $\begin{array}{l}\text { Maize, manioc, sweet } \\
\text { potatoes, beans, pea- } \\
\text { nuts, vegetables, rice, } \\
\text { papaya, mango }\end{array}$ & $\begin{array}{l}\text { Food supply, nutrient } \\
\text { suply and recycling, } \\
\text { decomposition of soil } \\
\text { organic matter }\end{array}$ \\
\hline \multirow{2}{*}{$\begin{array}{l}\text { Wild crops/ } \\
\text { fruit }\end{array}$} & Wild yams, & \multirow{2}{*}{$\begin{array}{l}\text { Biodiversity, food supply, } \\
\text { provision of pharmaceutical } \\
\text { components }\end{array}$} \\
\hline & Diverse plants & \\
\hline $\begin{array}{l}\text { Alternative } \\
\text { Fuel }\end{array}$ & $\begin{array}{l}\text { Jatropha, Ricinus } \\
\text { (castor oil) }\end{array}$ & $\begin{array}{l}\text { Natural regeneration, } \\
\text { restoration of degraded } \\
\text { land }\end{array}$ \\
\hline \multirow{2}{*}{$\begin{array}{l}\text { Domestic } \\
\text { Meat }\end{array}$} & \multirow[t]{2}{*}{ Large and small livestock } & Primary production, \\
\hline & & water supply \\
\hline $\begin{array}{l}\text { Fauna } \\
\text { diversity }\end{array}$ & Endemic species & Biodiversity \\
\hline Wood & Fuelwood, construction & $\begin{array}{l}\text { Biodiversity, biomass } \\
\text { accumulation, carbon } \\
\text { sequestration }\end{array}$ \\
\hline
\end{tabular}

Regulating Services

\begin{tabular}{|l|l|l|}
\hline $\begin{array}{l}\text { Climate } \\
\text { regulation }\end{array}$ & $\begin{array}{l}\text { Microclimate in different } \\
\text { forms of land use }\end{array}$ & Landatmosphere interaction \\
\hline $\begin{array}{l}\text { Pest and } \\
\text { disease } \\
\text { control }\end{array}$ & Food damage, & \multirow{2}{*}{ Natural selection } \\
\cline { 2 - 2 } & $\begin{array}{l}\text { Livestock parasites, Human } \\
\text { diseases }\end{array}$ & \\
\hline
\end{tabular}

Cultural Services

\begin{tabular}{|l|l|l|}
\hline \multirow{2}{*}{ Culture } & Sense of Place, & Biodiversity repositories for \\
& natural and degraded land \\
\cline { 2 - 3 } Recreation & Eco-tourism & $\begin{array}{l}\text { Aesthetic and intrinsic } \\
\text { beauty, tranquillity }\end{array}$ \\
\hline
\end{tabular}


From the perspective of the natural sciences, there is a substantial discrepancy between the issues listed in Table 1 and the current and past research agenda in Madagascar. Madagascar has been (and still is) the 'promised land' for the description of new species (summarized at the time by contributors to Goodman and Benstead 2003). These exciting discoveries drew a lot of funding into the country. But research of ecological processes hardly exists. Instead, patterns of species distribution have been used to derive ecological and evolutionary processes. Doing so, we replace experimental proof by correlation. We simply have next to no information on very basic issues that are relevant for these ecosystem functions and services, such as nutrient cycling, multitrophic interactions, the reactions of ecosystems towards disturbances (fire, cyclones, landslides, pest outbreaks) or simply the reaction of endemic flora and fauna towards anthropogenic habitats, not to mention mycorrhizae or soil microbiology (du Toit et al. 2004, Suding and Hobbs 2008, Reiss et al. 2009, Chapin III et al. 2009, Gardner 2009, Irwin et al. 2010).

While research in the natural sciences can follow the beaten paths and many issues will not be too difficult to analyze with a standard methodology, the existing knowledge of the natural ecosystem properties, socio-economic and cultural aspects are by far more complex and difficult to integrate into a comprehensive development scenario, that, despite all efforts, remains to be heavily influenced by our western thinking of values and needs. There, the key to success is mutual trust and personal respect. Both can only be achieved through long-term commitment by people who work with people (Sayer 2009); otherwise trust and respect are replaced by financial bonds and falter as soon as the money comes to an end. It takes years to really understand the mentality and needs of the local people. This can not be achieved on a two year contract.

Along the same line of argument, funding agencies might consider (or even request) to fund research that combines the social and natural science approaches. For the time being, this is simply hindered by the formal review process of applications because there are not enough people who can review interdisciplinary applications like this. Based on past experience, most researchers in the natural sciences and social sciences have had tremendous problems understanding each other. Certainly, this problem is amplified when researchers (foreigners as well as nationals) try to communicate with local people. While this is the case, we can not really expect progress in a field that needs to combine understanding of people and nature. The only solution can be provided by close collaborations between social and natural scientists, integrated in joint conservation and development activities.

\section{CONCLUSIONS}

This Spotlights contribution started with the perception that neither conservation nor development activities achieve what they intend to achieve. This is not a Malagasy phenomenon but seems to be the reality in most parts of the world where economic and biodiversity interests act in various combinations. Poverty and subsistence cultures without alternatives in a growing human population, as well as wealthy people in power and foreigners with preconceived agendas, aggravate the problem.

Social and environmental problems can not be addressed separately. From the social perspective, natural resource management has been too focused on conservation without considering the specific needs and constraints of the people who were affected by the conservation activities. From the natural science perspective, the social proponents could not make clear how comprehensive considerations of the specific local experiences would contribute to sustainable utilization of natural resources if traditional land use management evidently failed in view of a rapidly growing human population. While these considerations are not new and the insight, that Integrated Conservation and Development Projects often did not achieve what they set out to achieve, has been described in detail (Sayer 2009), integrated action as the most likely solution to this dilemma is still not implemented routinely. While it would be presumptuous to claim to be able to provide advice on how to solve this problem, there may be some ideas on how the situation could be improved. From a natural research perspective, possible steps in this direction might include:

- Most importantly: Improve communication at all levels.

- Request integrated research, but more importantly, integrated action from natural and social sciences.

- Create open access regional or a national database(s): Here, data collected by various research and development projects are stored, can be analyzed and made available to other projects.

- Implement external, interdisciplinary review of research, conservation and development projects: Organizations and people have to admit that they can make mistakes as we all do; learn from mistakes instead of hiding them. These mistakes should not be used for negative publicity but to allow others to benefit from previous experiences.

- supplement taxonomic research by research on ecosystem processes.

- supplement natural research in pristine ecosystems by research in disturbed systems that will define the ecological tolerance of species and their capacity to adapt to anthropogenic habitats.

- Embark on the planning of a comprehensive network of utilization, restoration and conservation activities that will result in a mosaic of land use forms and habitat connectivity on a regional and possibly national level.

With these considerations for long-term perspectives in mind, we should work towards a system that is based on reliable and sustainable economic benefits and thus build a network that is resilient to short-term natural disturbances, but also to mid-term political perturbations, and its associated changes in international engagements.

\section{ACKNOWLEDGEMENTS}

I sincerely thank three anonymous reviewers, as well as Patrick Waeber, Lucienne Wilmé and the team of SuLaMa / BMBF who outlined many shortcomings of this contribution, highlighted my limited understanding and provided insights that turned out as the central message of the article. If nothing else, the present contribution might at least help to illustrate the way of thinking of some (certainly not all) natural scientists. By identifying my errors in understanding, we may come to better collaborations between people concerned about human livelihoods within the framework of nature conservation. 


\section{REFERENCES}

Bishop, J., Kapila, S., Hicks, F., Mitchell, P. and Vorhies, F. 2008. Building Biodiversity Business. $164 \mathrm{pp}$. Shell International Limited and the International Union for Conservation of Nature, London, Gland.

Carpenter, S. R., Mooney, H. A., Agard, J., Capistrano, D., DeFries, R. S., Diaz, S., Dietz, T., Duraiappah, A. K., Oteng-Yeboah, A., Pereira, H. M., Perrings, C., Reid, W. V., Sarukhan, J., Scholes, R. J. and Whyte, A. 2009. Science for managing ecosystem services: Beyond the Millennium Ecosystem Assessment. Proceedings of the National Academy of Sciences of the United States of America 106, 5: 13051312. (doi:10.1073/pnas.0808772106)

Chapin III, F. S., Carpenter, S. R., Kofinas, G. P., Folke, C., Abel, N., Clark, W. C., Olsson, P., Smith, D. M. S., Walker, B., Young, O. R., Berkes, F., Biggs, R., Grove, J. M., Naylor, R. L., Pinkerton, E., Steffen, W. and Swanson, F. J. 2009. Ecosystem stewardship: Sustainability strategies for a rapidly changing planet. Trends in Ecology \& Evolution 25, 4: 241-249. (doi:10.1016/j.tree.2009.10.008)

de Groot, R. S., Wilson, M.A . and Boumans, R. M. J. 2002. A typology for the classification, description and valuation of ecosystem functions, goods and services. Ecological Economics 41, 3: 393-408. (doi:10.1016/S0921-8009(02)00089-7)

Deleporte, P., Randrianasolo, J. and Rakotonirina 1996. Sylviculture in the dry dense forest of western Madagascar. In: Ecology and Economy of a Tropical Dry Forest in Madagascar. J. U. Ganzhorn and J.-P. Sorg (eds.), pp 89-116. Primate Report 46-1, Göttingen.

Direction Générale de la Météorologie 2009. Le climat et le changement climatique à Madagascar. Antananarivo.

du Toit, J. T., Walker, B. H. and Campbell, B. M. 2004. Conserving tropical nature: Current challenges for ecologists. Trends in Ecology \& Evolution 19, 1: 12-17.

Durbin, J., Bernard, K. and Fenn, M. 2003. The role of socio-economic factors in loss of Malagasy biodiversity. In: The Natural History of Madagascar. S. M. Goodman and J. P. Benstead (eds.), pp 142-146. The University of Chicago Press, Chicago.

Durbin, J., Rakotoniaina, L. J., Andriananadrasana, H. T. \& Randriamahefasoa, J. 2008. Le projet Alaotra. In : Paysages Naturels et Biodiversité de Madagascar. S. M. Goodman (ed.), pp 627-637. Muséum national d'Histoire naturelle, Paris.

Ellis, E. C. and Ramankutty, N. 2008. Putting people in the map: Anthropogenic biomes of the world. Frontiers in Ecology and the Environment 6: 439-447. (doi:10.1890/070062)

Elmqvist, T., Pyykönen, M., Tengö, M., Rakotondrasoa, F., Rabakonandrianina, E. and Radimilahy, C. 2007. Patterns of loss and regeneration of tropical dry forest in Madagascar: the social institutional context. PLOS ONE 2,5: e402. (doi: 10.1371/journal. pone.0000402)

Ganzhorn, J. U. 1987. A possible role of plantations for primate conservation in Madagascar. American Journal of Primatology 12, 2: 205-215. (doi: 10.1002/ajp.1350120208)

Gardner, C. J. 2009. A review of the impacts of anthropogenic habitat change on terrestrial biodiversity in Madagascar: Implications for the design and management of new protected areas. Malagasy Nature 2: 2-29.

Goddard, M. A., Dougill, A. J. and Benton, T. G. 2010. Scaling up from gardens: Biodiversity conservation in urban environments. Trends in Ecology \& Evolution 25, 2: 90-98. (doi:10.1016/j.tree.2009.07.016)

Goodman, S. M. and Benstead, J. P. 2003. The Natural History of Madagascar. The University of Chicago Press, Chicago.

Goodman, S. M., Rakotondravony, D., Schatz, G. and Wilmé, L. 1996. Species richness of forest-dwelling birds, rodents and insectivores in a planted forest of native trees: A test case from Ankaratra, Madagascar. Ecotropica 2: 109-120.

Hannah, L., Dave, R., Lowry II, P. P., Andelman, S., Andrianarisata, M., Andriamaro, L., Cameron, A., Hijmans, R., Kremen, C., MacKinnon, J., Randrianasolo, H. H., Andriambololonera, S., Razafimpahanana, A., Randriamahazo, H., Randrianarisoa, J., Razafinjatovo, P., Raxworthy, C., Schatz, G. E., Tadross, M. and Wilmé, L. 2008. Climate change adaptation for conservation in Madagascar. Biology Letters 4, 5: 590-594. (doi:10.1098/rsbl.2008.0270)
Holloway, L. 2003. Ecosystem restoration and rehabilitation in Madagascar. In: The Natural History of Madagascar. S. M. Goodman and J. P. Benstead (eds.), pp 1444-1451. The University of Chicago Press, Chicago.

Hunt, C. 2008. Economy and ecology of emerging markets and credits for bio-sequestered carbon on private land in tropical Australia. Ecological Economics 66, 2-3: 309-318. (doi:10.1016/j.ecolecon.2007.09.012)

Innes, J. L. 2010. Madagascar rosewood, illegal logging and the tropical timber trade. Madagascar Conservation \& Development 5, 1: 6-10.

Irwin, M. T., Wright, P. C., Birkinshaw, C., Fisher, B. L., Gardner, C. J., Glos, J., Goodman, S. M., Loiselle, P., Rabeson, P., Raharison, J.-L., Raherilalao, M. J., Rakotondravony, D., Raselimanana, A., Ratsimbazafy, J., Sparks, J. S., Wilmé, L. and Ganzhorn, J. U. 2010. Patterns of species change in anthropogenically disturbed habitats of Madagascar. Biological Conservation 143, 10: 2351-2362. (doi:10.1016/j.biocon.2010.01.023)

Kremen, C., Cameron, A., Moilanen, A., Phillips, S. J., Thomas, C. D., Beentje, H., Dransfield, J., Fisher, B. L., Glaw, F., Good, T. C., Harper, G. J., Hijmans, R. J., Lees, D. C., Louis Jr., E., Nussbaum, R. A., Raxworthy, C. J., Razafimpahanana, A., Schatz, G. E., Vences, M., Vieites, D. R., Wright, P. C. and Zjhra, M. L. 2008. Aligning conservation priorities across taxa in Madagascar with high-resolution planning tools. Science 320: 222226. (doi:10.1126/science.1155193)

Missouri Botanical Garden. 2010. <http://www.tropicos.org> accessed 19 Nov 2010.

Patel, E. R. 2009. A tragedy with villains: Severe resurgence of selective rosewood logging in Marojejy National Park leads to temporary park closure. Lemur News 14: 1-6.

Plugge, D., Baldauf, T., Ratsimba, H. R., Rajoelison, G. and Köhl, M. 2010 Combined biomass inventory in the scope of REDD (Reducing Emissions from Deforestation and Forest Degradation). Madagascar Conservation \& Development 5, 1: 23-34.

Rabenantoandro, J., Randrihasipara, L., Randriatafika, F., Vincelette, M. and Rakoto, J. 2007. Testing the propagation and growth of the liana Flagellaria indica, used to make lobster traps, and Bambusa multiplex as an alternative source. In: Biodiversity, Ecology and Conservation of Littoral Forest Ecosystems in Southeastern Madagascar, Tolagnaro (Fort Dauphin). J. U. Ganzhorn, S. M. Goodman and M. Vincelette (eds.), pp 363-367. Smithsonian Institution, Washington D. C.

Rabesahala Horning, N. 2008. Strong support for weak performance: Donor competition in Madagascar. African Affairs 107: 405-431. (doi:10.1093/ afraf/adn036)

Randriamalala, H. and Liu, Z. 2010. Rosewood of Madagascar: Between democracy and conservation. Madagascar Conservation \& Development 5, 1: 11-22.

Randriatafika, F., Rabenantoandro, J. and Rajoharison, R. A. 2007a. Analyses of seed germination of littoral forest native species in southeastern Madagascar. In: Biodiversity, Ecology and Conservation of Littoral Forest Ecosystems in Southeastern Madagascar, Tolagnaro (Fort Dauphin). J. U. Ganzhorn, S. M. Goodman and M. Vincelette (eds.), pp 119-125. Smithsonian Institution, Washington D. C.

Randriatafika, F., Ramanamanjato, J.-B., Vincelette, M., Soloarivelo, S. and Randrihasipara, L. 2007b. Monitoring of biometric and ecological parameters following restoration of a Lepironia mucronata (Family Cyperaceae) wetland in Mandena. In: Biodiversity, Ecology and Conservation of Littoral Forest Ecosystems in Southeastern Madagascar, Tolagnaro (Fort Dauphin). J. U. Ganzhorn, S. M. Goodman and M. Vincelette (eds.), pp 355-362. Smithsonian Institution, Washington D. C.

Ratsirarson, J. 2008. La Réserve spéciale de Beza Mahafaly. In : Paysages Naturels et Biodiversité de Madagascar. S. M. Goodman (ed.), pp 615626. Muséum national d'Histoire naturelle, Paris..

Raxworthy, C. J., Pearson, R. G., Rabibisoa, N., Rakotondrazafy, A. M., Ramanamanjato, J.-B., Raselimanana, A. P., Wu, S., Nussbaum, R. A. and Stone, D. A., 2008. Extinction vulnerability of tropical montane endemism from warming and upslope displacement: A preliminary appraisal for the highest massif in Madagascar. Global Change Biology 14, 8: 1703-1720. (doi: 10.1111/j.1365-2486.2008.01596.x)

REBIOMA 2010. Reseau de la Biodiversité de Madagascar. <http://www. rebioma.net> accessed 19 November 2010 . 
Reid, W. V., Goldfarb, D. C., Hackmann, H., Lee, Y. T., Mokhele, K., Ostrom, E. Raivio, K., Rockström, J., Schellnhuber, H. J. and Whyte, A. 2010. Earth system science for global sustainability: Grand challenges. Science, 330: 916-917. (doi:10.1126/science.1196263)

Reiss, J., Bridle, J. R., Montoya, J. M. and Woodward, G. 2009. Emerging horizons in biodiversity and ecosystem functioning research. Trends in Ecology \& Evolution 24, 9: 505-514. (doi:10.1016/j.tree.2009.03.018)

RSSC 2010. Regional Science Service Centre (RSSC) in the Southern African sub-region. <http://www.rssc-southernafrica.net> accessed August 22, 2010).

Sayer, J. 2009. Can conservation and development really be integrated? Madagascar Conservation \& Development 4, 1: 9-12.

Schroth, G., da Fonesca, G. A. B., Harvey, C. A., Gascon, C., Vasconcelos, H. L. and Izac, A.-M. N. (eds.) 2004. Agroforestry and Biodiversity Conservation in Tropical Landscapes. Island Press, Washington D. C.

Serrao, E. A. 1995. Possibilities for sustainable agriculture development in the Brazilian Amazon: An Embrapa proposal. In: Brazilian Perspectives on Sustainable Development of the Amazon Region. M. ClüsenerGodt and I. Sachs (eds.), pp 259-285. Man and Biosphere series 15 Parthenon Publishing group, UNESCO, Paris.

Smith, A. P., Horning, N. and Moore, D. 1997. Regional biodiversity planning and lemur conservation with GIS in western Madagascar. Conservation Biology 11, 2: 498-512. (doi:10.1046/j.1523-1739.1997.95283.x)

Sorg, J. P. 2006. Orientations nouvelles de la recherche dans la zone des forêts denses sèches à Madagascar. C. Schwitzer, S. Brandt, D. Ackermand, O. Ramilijaona, G. Randria and J. U. Ganzhorn (eds.), pp 67-71, Concept Verlag, Berlin.

Suding, K. N. and Hobbs, R. J., 2009. Threshold models in restoration and conservation: A developing framework. Trends in Ecology \& Evolution 24, 5: 271-279. (doi:10.1016/j.tree.2008.11.012)

Vallan, D. 2002. Effects of anthropogenic environmental changes on amphibian diversity in the rain forests of eastern Madagascar. Journal of Tropical Ecology 18: 725-742. (doi:10.1017/S026646740200247X)

Vincelette, M., Rabenantoandro, J., Randrihasipara, L., Randriatafika, F. and Ganzhorn, J. U. 2007. Results from ten years of restoration experiments in the southeastern littoral forest of Madagascar. In: Biodiversity, Ecology and Conservation of Littoral Forest Ecosystems in Southeastern Madagascar, Tolagnaro (Fort Dauphin). J. U. Ganzhorn, S. M. Goodman and M. Vincelette (eds.), pp 337-354. Smithsonian Institution, Washington D. C.

Wilmé, L., Goodman, S. M. and Ganzhorn, J. U. 2006. Biogeographic evolution of Madagascar's microendemic biota. Science 312: 1063-1065. (doi:10.1126/science.1122806)

Wilmé, L., Schuurman, D. \& Lowry II, P.P. 2009. Fonds de contre-partie sylvestres. Les forêts de Madagascar, blessées, peuvent effacer leurs dettes pour sauver leur avenir, avec le soutien des citoyens de Madagascar. Lemur News 14: 7-9. 